\title{
WETENSCHAP
}

\section{Voorstel voor een nieuwe regeling voor de beëin- diging van de overblijvende aansprakelijkheid ex art. 2:404 BW}

\author{
E.A. van Dooren
}

\section{$1 \quad$ Inleiding}

Het groepsregime van art. 2:403 van het Burgerlijk Wetboek (BW) biedt een groepsmaatschappij de mogelijkheid om onder voorwaarden gebruik te maken van een jaarrekeningvrijstelling. De groepsmaatschappij (hierna: 403-maatschappij) is dan onder meer vrijgesteld van de verplichting om haar jaarrekening overeenkomstig de voorschriften van titel 9 van Boek 2 BW in te richten en deze openbaar te maken. Daarnaast mag zij de accountantscontrole achterwege laten. De jaarrekeningvrijstelling van het groepsregime biedt in de eerste plaats een administratieve lastenverlichting ${ }^{1}$ en zorgt er daarnaast voor dat kan worden voorkomen dat derden (concurrentiegevoelige) informatie uit de jaarrekening kunnen halen. ${ }^{2}$

Om gebruik te mogen maken van de jaarrekeningvrijstelling is onder meer vereist dat de financiële gegevens van de 403-maatschappij zijn geconsolideerd in de geconsolideerde jaarrekening van een rechtspersoon binnen de groep (hierna: moedermaatschappij), ${ }^{3}$ en dat deze moedermaatschappij schriftelijk heeft verklaard dat zij hoofdelijk aansprakelijk is voor de schulden die voortvloeien uit de rechtshandelingen van de 403-maatschappij (hierna: 403-verklaring). ${ }^{4}$

1 Kamerstukken II 1981/82, 16326, nr. 8, p. 20 (MvA) en nr. 13, p. 4 (NnavhEV), L.G.H.J. Houwen, A.P. Schoonbrood-Wessels \& J.A.W. Schreurs, Aansprakelijkheid in concernverhoudingen. Een rechtsvergelijkende studie naar de positie van crediteuren van concernafhankelijke vennootschappen in Duitsland, Frankrijk, Engeland en Nederland (diss. Nijmegen), Deventer: Kluwer 1993, p. 820, H. Beckman, Dient artikel 2:403 BW (groepsregime) in huidige vorm te worden geschrapt?, in: P. van Schilfgaarde e.a. (red.), Knelpunten in de vennootschapswetgeving: is met het oog hierop wijziging van de vennootschapswetgeving wenselijk?, Deventer: Kluwer 1995, p. 89 (hierna: Beckman 1995a), G.J.H. van der Sangen, Vraagpunten betreffende de 403-verklaring. Spijkers met koppen of spijkers op laag water?, TvOB 2017, afl. 6, p. 204, E.C.A. Nass, Groepsregime, jaarrekening en 403-aansprakelijkheid (diss. Groningen), Deventer: Wolters Kluwer 2019, p. 12 en Asser/Maeijer \& Kroeze 2-I* 2021/581.

2 H. Beckman, De jaarrekeningvrijstelling voor afhankelijke groepsmaatschappijen. Een analyse van artikel 2:403 BW en zijn voorgangers (diss. Groningen), Deventer: Kluwer 1995, p. 689 (hierna: Beckman 1995b), Van der Sangen 2017, p. 204, M.R.C. van Zoest, De groepsvrijstelling in de praktijk, Zutphen: Uitgeverij Paris 2019, p. 9, Nass 2019, p. 13-14 en Asser/Maeijer \& Kroeze 2-I* 2021/581.

3 Zie art. 2:403 lid 1 sub c BW.

4 Zie art. 2:403 lid 1 sub $\mathrm{f} B W$. 
Als een 403-maatschappij gebruikmaakt van de jaarrekeningvrijstelling kunnen derden de jaarrekening niet inzien. Hierdoor ontbreekt het bijvoorbeeld de crediteuren aan de mogelijkheid om (mede) aan de hand van de jaarrekening te schatten hoe groot het risico is dat hun vorderingen niet (volledig) zullen worden voldaan. Crediteuren van wie de vordering voortvloeit uit een rechtshandeling van de 403-maatschappij worden voor dit gebrek aan inzicht gecompenseerd doordat zij op grond van de 403-verklaring een aanvullende vordering hebben op de moedermaatschappij waarvan zij de geconsolideerde jaarrekening wel kunnen inzien. Ter compensatie van het feit dat zij een vordering hebben op een debiteur - de 403-maatschappij - van wie zij de jaarrekening niet kunnen inzien, krijgen zij een aanvullende vordering op een andere debiteur - de moedermaatschappij - van wie zij de geconsolideerde jaarrekening wel kunnen inzien.

Het is mogelijk dat een moedermaatschappij op een later moment haar 403-verklaring weer intrekt door de deponering van een daartoe strekkende verklaring, een zogenoemde 'intrekkingsverklaring'. ${ }^{5}$ De moedermaatschappij blijft echter aansprakelijk voor de schulden die zijn voortgevloeid en in de toekomst nog voortvloeien uit de rechtshandelingen die de 403-maatschappij heeft verricht tot het moment dat de moedermaatschappij tegenover de crediteur een beroep kan doen op de intrekking. ${ }^{6}$ Deze zogenoemde 'overblijvende aansprakelijkheid' kan de moedermaatschappij beëindigen indien aan de vier cumulatieve vereisten van art. 2:404 lid 3 sub a tot en met sub d BW wordt voldaan.

Om de overblijvende aansprakelijkheid te beëindigen is vereist dat de groepsband tussen de moeder- en de 403-maatschappij is verbroken (sub a). Voorts moet er twee maanden een mededeling van het voornemen om de overblijvende aansprakelijkheid te beëindigen ter inzage hebben gelegen bij het handelsregister (sub b) en dienen er twee maanden te zijn verlopen na de aankondiging van deze mededeling in een landelijk verspreid dagblad (sub c). Tot slot mag tegen het voornemen tot beëindiging geen verzet zijn ingesteld door de crediteur, dan wel moet diens verzet zijn ingetrokken of door de rechter ongegrond zijn verklaard (sub d). Een crediteur die verzet heeft ingesteld, heeft onder omstandigheden recht op een vervangende waarborg voor de voldoening van zijn vordering op de 403-maatschappij. ${ }^{7}$ p. 225.

6 Kamerstukken II 1983/84, 16551, nr. 11, p. 15 (NnavhEV), M.P. van Achterberg, De juridische definitie van het economisch verschijnsel concern in het ondernemingsrecht. Een beschouwing over de problemen die samenhangen met de juridische definiëring van het economisch verschijnsel concern, mede aan de hand van de definitieproblematiek die in de geconsolideerde jaarrekening naar voren komt (diss. Amsterdam VU), Deventer: Kluwer 1989, p. 229, S.M. Bartman, Werkgeversverplichtingen onder de art. 403-verklaring, ArbeidsRecht 2002, afl. 6/7, p. 24-25, T. van Wijngaarden, Verantwoording over het groepsregime, in: M.J. Kroeze, C.M. Harmsen, M.W. Josephus Jitta, L. Timmerman, J.B. Wezeman \& P.M. van der Zanden (red.), Verantwoording aan Hans Beckman, Deventer: Kluwer 2006, p. 619, J.P.H. Zwemmer, Pluraliteit van werkgeverschap, Deventer: Kluwer 2012, p. 238-239, Beckman, in: Sdu Commentaar Ondernemingsrecht 2019, art. 2:404 BW, aant. C.1, Van Zoest 2019, p. 32-33, Nass 2019, p. 141 en 231 en Bartman, Dorresteijn \& Olaerts 2020, p. 226-227.

7 Zie art. 2:404 lid 4 t/m 6 BW. 
Bij de introductie van vorenstaande regeling verklaarde de minister dat met de genoemde voorwaarden het evenwicht wordt bewaard tussen het belang van een crediteur die heeft vertrouwd op de aansprakelijkheid van de moedermaatschappij en het belang van de moedermaatschappij dat de 403-aansprakelijkheid niet nog jaren doorloopt nadat de banden met de 403-maatschappij zijn verbroken. ${ }^{8}$ Ik deel deze opvatting van de minister niet. Naar mijn mening is de beëindiging van de overblijvende aansprakelijkheid volgens de huidige regeling - en de uitleg daarvan in de jurisprudentie - nodeloos belastend voor de moedermaatschappij en werkt deze in de hand dat een moedermaatschappij probeert de procedure zo veel mogelijk onder de radar te doorlopen. Ik pleit er daarom voor dat deze regeling op bepaalde punten anders wordt uitgelegd in de jurisprudentie, en dat art. 2:404 BW daarnaast op sommige plekken wordt gewijzigd.

Hierna zal ik ten aanzien van voornoemde vier voorwaarden voor de beëindiging van de overblijvende aansprakelijkheid een uiteenzetting geven hoe deze mijns inziens anders moeten worden uitgelegd of moeten worden aangepast. ${ }^{9}$ In verband met de duidelijkheid kies ik ervoor om deze voorwaarden in een andere volgorde te behandelen dan die waarin zij in sub a tot en met d van art. 2:404 lid 3 BW staan. Ik begin met een bespreking van de voorwaarden uit sub $b$ en $c$ dat de moedermaatschappij een mededeling van haar voornemen om de overblijvende aansprakelijkheid te beëindigen moet deponeren bij het handelsregister en een aankondiging van deze mededeling moet plaatsen in een landelijk verspreid dagblad (par. 2). Vervolgens ga ik in op de mogelijkheid voor crediteuren om verzet in te stellen tegen de voorgenomen beëindiging en om een vervangende waarborg te verzoeken. De bespreking van het verzetsrecht en het recht op een vervangende waarborg valt uiteen in de beantwoording van drie vragen. Ten eerste onderzoek ik welke crediteuren verzet kunnen instellen (par. 3). Vervolgens geef ik antwoord op de vraag onder welke omstandigheden een crediteur die verzet heeft ingesteld recht heeft op een vervangende waarborg (par. 4). Aansluitend onderzoek ik welke omvang deze vervangende waarborg moet hebben (par. 5). De laatste voorwaarde van art. 2:404 lid 3 BW die ik behandel, is het vereiste ex sub a dat de 403-maatschappij de groep van de moedermaatschappij moet hebben verlaten (par. 6).

\section{Mededeling in het handelsregister en aankondiging in een landelijk verspreid dagblad}

Voor crediteuren kan de beëindiging van de overblijvende aansprakelijkheid grote gevolgen hebben omdat zij daardoor hun verhaalsrecht op de moedermaatschappij verliezen. Om crediteuren in staat te stellen hiertegen verzet in te stellen en om een vervangende waarborg te verzoeken, moet de moedermaatschappij haar voornemen om de overblijvende aansprakelijkheid te beëindigen op twee manieren

8 Kamerstukken II 1983/84, 16551, nr. 11, p. 15 (NnavhEV).

9 Deze bijdrage is deels een bewerking van het proefschrift van de auteur: E.A. van Dooren, De aansprakelijkheid op grond van een 403-verklaring (Uitgaven vanwege het Instituut voor Ondernemingsrecht, deel 122), Deventer: Wolters Kluwer 2021. 
kenbaar maken. Allereerst moet zij een mededeling van dit voornemen deponeren bij het handelsregister. ${ }^{10}$ Daarnaast moet zij een aankondiging plaatsen in een landelijk verspreid dagblad dat en waar deze mededeling ter inzage ligt. ${ }^{11}$ Er moeten ten minste twee maanden zijn verlopen na de deponering bij het handelsregister en de aankondiging in een landelijk verspreid dagblad.

Evenals Berk meen ik dat het onwaarschijnlijk is dat een crediteur dagelijks alle landelijk verspreide dagbladen controleert en regelmatig voor alle debiteuren nagaat of er een mededeling is gedeponeerd van het voornemen om de overblijvende aansprakelijkheid te beëindigen. ${ }^{12}$ Het is daarom zeker niet ondenkbaar dat een crediteur een aangekondigde beëindiging van de overblijvende aansprakelijkheid over het hoofd ziet en hij zonder het te weten zijn verhaalsrecht op de moedermaatschappij is verloren.

Ik heb twee bezwaren tegen een publicatie in een landelijk verspreid dagblad als medium om bekend te maken dat de moedermaatschappij de overblijvende aansprakelijkheid wil beëindigen. Ten eerste wijs ik op de digitalisering van de samenleving, waardoor het belang van kranten als bron van informatie is afgenomen. Daarnaast geeft de wet geen definitie van een landelijk verspreid dagblad, waardoor onduidelijk is welke dagbladen als zodanig kwalificeren. Hierdoor is niet met zekerheid te zeggen welke dagbladen de crediteuren moeten bijhouden en waar een moedermaatschappij de aankondiging kan publiceren. Uit de jurisprudentie volgt slechts dat het Nederlands Dagblad en het Reformatorisch Dagblad geen landelijk verspreid dagblad zijn omdat zij een (relatief) beperkte oplage hebben ${ }^{13}$ en zich richten op een specifieke doelgroep in Nederland - lezers met een orthodoxe protestante, respectievelijk een gereformeerde achtergrond. ${ }^{14}$

De huidige technische mogelijkheden bieden mijns inziens een eenvoudiger en effectiever alternatief dat crediteuren beter in staat stelt om op de hoogte te kunnen zijn van het voornemen van de moedermaatschappij om de overblijvende aansprakelijkheid te beëindigen. Ik sluit mij aan bij Van Zoest, die betoogt dat de Kamer van Koophandel een systeem moet aanbieden waarbij derden automatisch een notificatie kunnen krijgen als met betrekking tot een bepaalde rechtspersoon stukken zijn gedeponeerd bij het handelsregister. ${ }^{15}$ Een dergelijk systeem geeft een cre-

10 Art. 2:404 lid 3 sub b BW. Zie Van Zoest 2019, p. 36, die een voorbeeld geeft hoe een dergelijke mededeling eruit kan zien.

11 Art. 2:404 lid 3 sub c BW. Zie Van Zoest 2019, p. 37, die een voorbeeld geeft hoe een dergelijke aankondiging eruit kan zien.

12 J.W. Berk, Enkele opmerkingen bij artikel 403 boek 2 burgerlijk wetboek, O\&F 2007, afl. 76, p. 18.

13 Het Nederlands Dagblad had in 1991 een oplage van 25.496 abonnees en een losse verkoop van 25 stuks per dag (zie Hof Amsterdam (OK) 29 juli 1993, ECLI:NL:GHAMS:1993:AD1931, NJ 1994/132 (Teeuwissen/Teletrade), r.o. 3.14). Het Reformatorisch Dagblad had in 2001 een oplage van circa 57.810 abonnementen en was daarnaast bij enkele tientallen verkooppunten in Nederland los te koop (zie Rb. 's-Hertogenbosch 21 februari 2002, ECLI:NL:RBSHE:2002:AD9620 (Landis/ Norted International), r.o. 4.4).

14 Hof Amsterdam (OK) 29 juli 1993, ECLI:NL:GHAMS:1993:AD1931, NJ 1994/132 (Teeuwissen/ Teletrade), r.o. 6.5 en Rb. 's-Hertogenbosch 21 februari 2002, ECLI:NL:RBSHE:2002:AD9620 (Landis/Norted International), r.o. 4.4.

15 M.R.C. van Zoest, (Beëindiging van) 403-aansprakelijkheid. De stand van zaken anno 2016, O\&F 2016, afl. 1, p. 64. 
diteur onder meer de mogelijkheid dat hij een bericht krijgt als de moedermaatschappij een mededeling deponeert van het voornemen om de overblijvende aansprakelijkheid te beëindigen.

Met de introductie van voornoemd systeem waarmee derden notificaties kunnen krijgen, is naar mijn mening voldoende gewaarborgd dat een crediteur op de hoogte kan zijn van een door de moedermaatschappij bij het handelsregister gedeponeerde mededeling van het voornemen om de overblijvende aansprakelijkheid te beëindigen. In dat geval kan het vereiste van de publicatie in een landelijk dagblad worden geschrapt als voorwaarde om de overblijvende aansprakelijkheid te beëindigen.

\section{Wie kunnen verzet instellen tegen de beëindiging van de overblijvende aansprakelijkheid?}

Op grond van art. 2:404 lid 5 BW heeft een crediteur twee maanden de tijd om verzet in te stellen tegen het voornemen van de moedermaatschappij om de overblijvende aansprakelijkheid te beëindigen. De verzetstermijn vangt aan ${ }^{16}$ op de eerste dag na de publicatie in een landelijk verspreid dagblad dat de moedermaatschappij een mededeling heeft gedeponeerd van het voornemen om de overblijvende aansprakelijkheid te beëindigen. ${ }^{17}$ Het instellen van verzet heeft een privatieve werking. Slechts ten aanzien van de crediteuren die verzet hebben ingesteld, eindigt de overblijvende aansprakelijkheid van de moedermaatschappij (nog) niet. De moedermaatschappij is wel bevrijd van haar aansprakelijkheid tegenover de crediteuren die geen verzet hebben ingesteld. ${ }^{18}$

Art. 2:404 lid 5 BW schrijft voor dat een crediteur 'voor wiens vordering nog aansprakelijkheid loopt' verzet kan instellen tegen het voornemen van de moedermaatschappij om de overblijvende aansprakelijkheid te beëindigen. De vordering waarnaar in deze bepaling wordt verwezen, is de vordering van de crediteur op de 403-maatschappij - waarvoor de moedermaatschappij op grond van de 403-verkla-

16 Indien mijn voorstel wordt overgenomen om het vereiste van een publicatie in een landelijk dagblad te schrappen als voorwaarde om de overblijvende aansprakelijkheid te beëindigen (zie par. 2 van deze bijdrage), vangt de verzetstermijn aan op de dag nadat de Kamer van Koophandel de door de moedermaatschappij gedeponeerde mededeling van het voornemen van de beëindiging heeft verwerkt in het handelsregister.

17 Op de verzetstermijn is de Algemene termijnenwet (ATW) van toepassing. Dit brengt mee dat in het geval dat de verzetstermijn eindigt op een dag in het weekend of een algemeen erkende feestdag, de termijn op grond van art. 1 lid 1 ATW wordt verlengd tot en met de eerstvolgende dag die geen weekenddag of algemeen erkende feestdag is. De verzetstermijn kan wel op een dergelijke dag aanvangen.

18 Beckman 1995b, p. 347, H. Beckman \& E.A. Marseille, Hoofdlijnen van het jaarrekeningenrecht in Nederland, Deventer: Kluwer 2013, p. 286, B. Snijder-Kuipers \& M.F. Eliëns, Praktische vraagstukken bij beëindiging van overblijvende aansprakelijkheid (2:404 BW), WPNR 2014, afl. 7042, p. 1179, C.R. Huiskes, Enige beschouwingen omtrent de '403-verklaring', TvJ 2015, afl. 2, p. 44, K. Notenboom, Het verzetrecht van artikel 2:404 BW, MvO 2017, afl. 5/6, p. 128, Van Zoest 2019, p. 39 en Asser/Maeijer \& Kroeze 2-I*2021/586. 
ring aansprakelijk is. ${ }^{19}$ In de jurisprudentie is een aantal keer de vraag aan de orde gekomen of vorenstaande formulering in art. 2:404 lid 5 BW ruimte laat dat ook crediteuren ${ }^{20}$ met een (nog) niet-vaststaande vordering op de 403-maatschappij verzet kunnen instellen tegen het voornemen van de moedermaatschappij om de overblijvende aansprakelijkheid te beëindigen. De rechtbank Rotterdam heeft in 2015 geoordeeld dat de enkele betwisting van het bestaan van de vordering op de 403-maatschappij in ieder geval niet per definitie meebrengt dat de crediteur geen verzet kan instellen. Om verzet te kunnen instellen is volgens de rechtbank vereist dat het bestaan van de vordering voldoende aannemelijk is. ${ }^{21}$ In 2017 heeft ook de Hoge Raad zich over deze vraag gebogen in zijn beschikking inzake SNS/Curatoren. ${ }^{22}$ In casu waren er diverse crediteuren met niet-vaststaande vorderingen op de 403-maatschappij die verzet hebben ingesteld tegen het voornemen van de moedermaatschappij om de overblijvende aansprakelijkheid te beëindigen.

Ten eerste is verzet ingesteld door crediteuren die van mening waren dat zij een vordering tot schadevergoeding hadden op de 403-maatschappij wegens een schending van de bancaire zorgvuldigheidsverplichting door laatstgenoemde. De 403-maatschappij heeft deze vorderingen betwist en ten tijde van het verzet waren de vorderingen nog niet in rechte aan de crediteuren toegewezen. Daarnaast is verzet ingesteld door een crediteur met een voorwaardelijke vordering op de 403-maatschappij. De crediteur beriep zich daarvoor op een garantieverklaring op grond waarvan de 403-maatschappij zich subsidiair aansprakelijk had gesteld voor de verplichtingen van een derde jegens de crediteur. Op het moment van het verzet had de crediteur nog geen beroep gedaan op de garantie.

De Hoge Raad overweegt dat de regeling inzake de beëindiging van de overblijvende aansprakelijkheid het evenwicht bewaart tussen enerzijds het belang van de crediteur die heeft vertrouwd op de aansprakelijkheid van de moedermaatschappij, en anderzijds het belang van de moedermaatschappij die deze aansprakelijkheid wil beëindigen. ${ }^{23}$ Hij vervolgt dat dit vertrouwen van de crediteur - op de aansprakelijkheid van de moedermaatschappij - bescherming verdient bij beëindiging van de overblijvende aansprakelijkheid. Aangezien in de verzetsprocedure niet wordt geoordeeld over de toewijsbaarheid van de vordering van de crediteur op de 403-maatschappij, moet de rechter - als het bestaan van de vordering is betwist - het verzet van de crediteur in beginsel erkennen, tenzij en voor zover de vordering onmiskenbaar ongegrond is.

Vorenstaande uitspraken zijn in de literatuur verschillend ontvangen. Bartman en Van der Kraan zijn het niet eens met de genoemde uitspraken en vragen zich af of

19 Notenboom 2017, p. 128 en S.M. Bartman, De 403-verklaring: hoofdelijkheid of borgtocht? Een napleitexercitie, AA 2015, afl. 10, p. 809.

20 Het gebruik van de term crediteur is op dit punt strikt genomen niet correct omdat de desbetreffende partij nog geen (vaststaande) vordering op de 403-maatschappij heeft. In verband met de leesbaarheid zal ik deze term toch gebruiken.

21 Rb. Rotterdam 29 september 2015, ECLI:NL:RBROT:2015:7610, JOR 2015/295, m.nt. Bartman (Iemants/Hertel Beheer), r.o. 4.7.

22 HR 31 maart 2017, ECLI:NL:HR:2017:546, JOR 2017/221, m.nt. De Haan (SNS/Curatoren).

23 HR 31 maart 2017, ECLI:NL:HR:2017:546, JOR 2017/221, m.nt. De Haan (SNS/Curatoren), r.o. 5.1.4-5.1.6. 
het recht om verzet in te stellen niet te ruimhartig wordt toegekend. ${ }^{24} \mathrm{Zij}$ menen dat de tekst van art. 2:404 lid 5 BW, dat een crediteur 'voor wiens vordering nog aansprakelijkheid loopt' verzet kan instellen, strikt moet worden uitgelegd. Volgens hen zouden alleen crediteuren met een vaststaande vordering op de 403-maatschappij - waarvoor aansprakelijkheid loopt - verzet moeten kunnen instellen. Bartman wijst erop dat het groepsregime een faciliteit is voor groepsstructuren, op grond waarvan een groepsmaatschappij gebruik kan maken van een jaarrekeningvrijstelling. De moedermaatschappij moet zich volgens hem daarom betrekkelijk eenvoudig kunnen kwijten van de aansprakelijkheid op grond van een in het verleden vrijwillig gedeponeerde 403-verklaring. Daarbij past een restrictieve uitleg van de kring van verzetsgerechtigden. ${ }^{25}$ Van der Kraan merkt daarnaast op dat als een ingesteld verzet te snel wordt erkend, de crediteuren hiervan misbruik kunnen maken. ${ }^{26}$ Onder druk van het mogelijk tegen zich moeten dulden van het verzet van een crediteur met een summier onderbouwde vordering kan een moedermaatschappij wellicht bereid zijn om met de crediteur te schikken, terwijl zij hier eerder weinig voor voelde.

In tegenstelling tot Bartman en Van der Kraan staan de meeste auteurs wel positief tegenover het oordeel van de Hoge Raad. ${ }^{27}$ Ik sluit mij hierbij aan en wijs op drie punten ter onderbouwing van dit standpunt. Ten eerste is de beëindiging van de overblijvende aansprakelijkheid onomkeerbaar. Dit betekent dat als een crediteur geen verzet kan instellen - omdat zijn vordering op de 403-maatschappij (nog) niet vaststaat -, hij zich nooit meer op grond van de (ingetrokken) 403-verklaring op de moedermaatschappij kan verhalen. Zelfs niet als later blijkt dat hij een rechtsgeldige vordering op de 403-maatschappij heeft. Mijns inziens zou onterecht afbreuk worden gedaan aan de bescherming uit hoofde van art. 2:404 lid 5 BW als crediteuren met een betwiste of voorwaardelijke vordering op de 403-maatschap-

24 Bartman in zijn annotaties onder Rb. Rotterdam 29 september 2015, ECLI:NL:RBROT:2015:7610, JOR 2015/295 (Iemants/Hertel Beheer) en Hof Amsterdam (OK) 9 december 2015, ECLI:NL: GHAMS:2015:5141, JOR 2016/7 (Curatoren/SNS), Van der Kraan in zijn annotatie onder Hof Amsterdam (OK) 9 december 2015, ECLI:NL:GHAMS:2015:5141, JIN 2016/12 (Curatoren/SNS), J. van der Kraan, De toetsing van de hardheid van een vordering in een verzetprocedure op basis van artikel 2:404 lid 5 BW, MvO 2016, afl. 1, p. 11-14, S.M. Bartman \& J. van der Kraan, Beëindiging overblijvende aansprakelijkheid conform artikel 2:404 BW? Anders de Hoge Raad, AA 2017, afl. 11, p. 924-926 en J. van der Kraan, Het toelaten en het toekennen van schuldeisersverzet op grond van art. 2:404 BW, JBN 2018/3, p. 8-9.

25 Bartman in zijn annotaties onder Rb. Rotterdam 29 september 2015, ECLI:NL:RBROT:2015:7610, JOR 2015/295 (Iemants/Hertel Beheer) en Hof Amsterdam (OK) 9 december 2015, ECLI:NL: GHAMS:2015:5141, JOR 2016/7 (Curatoren/SNS).

26 Van der Kraan 2016, p. 10 en Van der Kraan 2018, p. 8-9.

27 M.R.C. van Zoest, De nieuwe maatstaf van de Hoge Raad bij 403-aansprakelijkheid: 'onmiskenbaar ongegrond', O\&F 2017, afl. 2, p. 63, P.S. Bakker, Enige opmerkingen over de 403-verklaring en de maatstaf bij verzet tegen de intrekking van overblijvende aansprakelijkheid, ORP 2018, afl. 3, p. 1820, C.E.J.M. Hanegraaf, SNS, een drama in drie bedrijven. Tweede bedrijf: de 403 -verklaring en de (voorgenomen) beëindiging van de overblijvende aansprakelijkheid ex artikel 2:404 BW, Bb 2019, afl. 13, p. 186 en Van Schilfgaarde, De Haan en Schepel in hun annotaties onder HR 31 maart 2017, ECLI:NL:HR:2017:546, NJ 2018/26; JOR 2017/221; JIN 2017/97 (SNS/Curatoren). Zie ook E.A. van Dooren, Ontvankelijkheid cassatieberoep; verzet tegen de beëindiging van overblijvende aansprakelijkheid, Ondernemingsrecht 2017/91, p. 514. 
pij geen verzet kunnen instellen tegen het voornemen van de moedermaatschappij om de overblijvende aansprakelijkheid te beëindigen.

Daarnaast merk ik op dat een crediteur van de 403-maatschappij geen invloed heeft op de keuze van de moedermaatschappij om de overblijvende aansprakelijkheid te beëindigen noch op het moment dat de moedermaatschappij hiertoe overgaat. Ik meen daarom dat als de moedermaatschappij de procedure om de overblijvende aansprakelijkheid te beëindigen begint op een moment dat de vordering van de crediteur op de 403-maatschappij (nog) niet vaststaat, dit er niet toe mag leiden dat de crediteur zonder meer zijn (potentiële) verhaalsrecht tegenover de moedermaatschappij verliest. Hij moet de mogelijkheid hebben om gebruik te maken van de waarborgen die zijn bedoeld om dit (potentiële) verhaalsrecht te beschermen. Een derde reden waarom art. 2:404 lid 5 BW naar mijn mening zo moet worden uitgelegd dat ook crediteuren met een niet-vaststaande vordering op de 403-maatschappij verzet kunnen instellen tegen het voornemen van de moedermaatschappij om de overblijvende aansprakelijkheid te beëindigen, is omdat dit aansluit bij het verzetsrecht voor crediteuren op grond van art. 2:316 en 2:334l BW in het geval dat een rechtspersoon wil fuseren of splitsen. Ook bij een voorgenomen fusie of splitsing wordt aangenomen dat een crediteur met een betwiste of voorwaardelijke vordering hiertegen verzet kan instellen, tenzij de vordering op voorhand ongegrond voorkomt. ${ }^{28}$

Ik ben mij ervan bewust dat het nadelig kan zijn voor een moedermaatschappij dat crediteuren met een niet-vaststaande vordering op de 403-maatschappij verzet kunnen instellen tegen het voornemen om de overblijvende aansprakelijkheid te beëindigen. Het risico bestaat dat de moedermaatschappij een tegen dit voornemen ingesteld verzet tegen zich moet dulden, terwijl later blijkt dat de crediteur geen (rechtsgeldige) vordering op de 403-maatschappij heeft. In een dergelijk geval is de vermeende overblijvende aansprakelijkheid van de moedermaatschappij tegenover deze crediteur blijven bestaan of heeft de moedermaatschappij een (voorwaardelijke) vervangende waarborg moeten geven. Op het moment echter dat vast komt te staan dat de crediteur toch geen (rechtsgeldige) vordering op de 403-maatschappij heeft, komt daarmee ook vast te staan dat de crediteur geen vordering heeft op de moedermaatschappij of vervalt de gegeven (voorwaardelijke) vervangende waarborg.

Naar mijn mening weegt voornoemd nadeel voor de moedermaatschappij niet op tegen het nadeel dat een crediteur met een niet-vaststaande vordering op de 403-maatschappij zou ondervinden als hij geen verzet zou kunnen instellen tegen het voornemen van de moedermaatschappij om de overblijvende aansprakelijkheid te beëindigen. Hij verliest dan blijvend de mogelijkheid om de moedermaatschappij aansprakelijk te stellen indien naderhand blijkt dat hij toch een rechtsgeldige vordering heeft op de 403-maatschappij.

Het is vanzelfsprekend niet de bedoeling dat iedereen die zegt een vordering te hebben op de 403-maatschappij verzet kan instellen tegen het voornemen van de 
moedermaatschappij om de overblijvende aansprakelijkheid te beëindigen. Er moet iets van een drempel zijn. Ik onderschrijf op dit punt het oordeel van de Hoge Raad in de SNS/Curatoren-beschikking dat het verzet van een crediteur moet worden erkend, tenzij de vordering onmiskenbaar ongegrond is ${ }^{29}$ Een dergelijke beperkte toets doet recht aan het onherroepelijke karakter van de beëindiging van de overblijvende aansprakelijkheid en het feit dat een crediteur geen invloed heeft op het moment waarop de moedermaatschappij besluit de procedure daartoe te starten. ${ }^{30}$

\section{Onder welke omstandigheden heeft een crediteur recht op een vervan- gende waarborg?}

Op grond van art. 2:404 lid 4 BW kan een crediteur die verzet heeft ingesteld tegen het voornemen van de moedermaatschappij om de overblijvende aansprakelijkheid te beëindigen een vervangende waarborg verlangen voor de voldoening van zijn vordering op de 403-maatschappij. De crediteur heeft geen recht op een vervangende waarborg als hij na de beëindiging van de overblijvende aansprakelijkheid nog voldoende andere waarborgen heeft, uit hoofde van de vermogenstoestand van de 403-maatschappij of uit anderen hoofde, dat zijn vordering op de 403-maatschappij zal worden voldaan. Van een waarborg uit anderen hoofde is bijvoorbeeld sprake als de crediteur een recht van pand of hypotheek heeft tot zekerheid van nakoming van de vordering of als een andere rechtspersoon - die de aandelen in de 403-maatschappij heeft overgenomen van de moedermaatschappij - zich ook door middel van een 403-verklaring aansprakelijk heeft gesteld voor de schulden die voortvloeien uit de rechtshandelingen van de 403 -maatschappij. ${ }^{31} \mathrm{De}$ bewijslast dat een crediteur geen recht heeft op een vervangende waarborg ligt bij de moedermaatschappij. ${ }^{32}$

Welke waarborg de vermogenstoestand van de 403-maatschappij biedt dat de vordering van de crediteur zal worden voldaan, moet worden beoordeeld aan de hand van de omstandigheden van het geval. ${ }^{33}$ In de jurisprudentie is onder meer gewezen op het eigen vermogen, de liquiditeit en de solvabiliteit van de 403-maatschap-

29 HR 31 maart 2017, ECLI:NL:HR:2017:546, JOR 2017/221, m.nt. De Haan (SNS/Curatoren), r.o. 5.1.6.

30 Van Dooren 2017, p. 514.

31 Ervan uitgaande dat de aansprakelijkheid op grond van een 403-verklaring alle schulden omvat die voortvloeien en zijn voortgevloeid uit een rechtshandeling die de 403-maatschappij heeft verricht. Zie Van Dooren 2021, p. 187-195 en de daar genoemde literatuur, jurisprudentie en parlementaire geschiedenis.

32 Hof Amsterdam (OK) 31 juli 2001, JOR 2001/170, m.nt. Bartman (ING/Akzo), r.o. 4.12, Rb. Midden-Nederland 5 november 2014, ECLI:NL:RBMNE:2014:5519 (Curatoren/SNS), r.o. 2.2, Rb. Rotterdam 29 september 2015, ECLI:NL:RBROT:2015:7610, JOR 2015/295, m.nt. Bartman (Iemants/ Hertel Beheer), r.o. 4.11 en Hof Amsterdam (OK) 9 december 2015, ECLI:NL:GHAMS:2015:5141, JOR 2016/7, m.nt. Bartman (Curatoren/SNS), r.o. 3.19.

33 H. Beckman e.a. (red.), Compendium voor de jaarrekening, Deventer: Kluwer Bedrijfsinformatie, par. 3.8.6.6.c. 
pij. ${ }^{34}$ Daarnaast is niet alleen de huidige vermogenstoestand van de 403-maatschappij van belang, maar spelen ook de te verwachten toekomstige ontwikkelingen een rol. Tot slot moeten eventuele toezeggingen of verwachtingen dat de 403-maatschappij in de toekomst financieel ondersteund zal worden, voldoende concreet zijn. ${ }^{35}$

De Hoge Raad oordeelt in zijn SNS/Curatoren-beschikking dat voor de beantwoording van de vraag of een crediteur na de beëindiging van de overblijvende aansprakelijkheid voldoende waarborgen heeft dat zijn vordering op de 403-maatschappij zal worden voldaan, beoordeeld moet worden of zijn positie door deze beëindiging al of niet verzwakt. ${ }^{36}$

Volgens Bartman en Van der Kraan sluit het oordeel van de Hoge Raad niet aan bij de toets van art. 2:404 lid 4 BW. Zij zijn van mening dat de positie van een crediteur door de beëindiging van de overblijvende aansprakelijkheid altijd verzwakt omdat hij daardoor zijn vordering op de moedermaatschappij verliest. In plaats van een vordering op de moeder- en op de 403-maatschappij heeft de crediteur na de beëindiging alleen nog een vordering op de 403-maatschappij. ${ }^{37}$ Dit betekent dat iedere crediteur die verzet instelt altijd recht heeft op een vervangende waarborg. Deze uitkomst is volgens hen in strijd met art. 2:404 lid 4 BW, welke bepaling expliciet wél de mogelijkheid noemt dat een crediteur die verzet instelt geen recht heeft op een vervangende waarborg.

Evenals Hanegraaf kan ik mij niet vinden in vorenstaande interpretatie van het oordeel van de Hoge Raad door Bartman en Van der Kraan. ${ }^{38}$ Juist omdat deze interpretatie betekent dat het oordeel van de Hoge Raad in strijd is met art. 2:404 lid 4 BW, denk ik dat dit oordeel anders moet worden uitgelegd. Ik merk op dat de toets ex art. 2:404 lid 4 BW of een crediteur die verzet heeft ingesteld recht heeft op een vervangende waarborg, onderdeel is van de procedure om de compensatie te beëindigen die de crediteuren ontvangen omdat zij de jaarrekening van de 403-maatschappij niet (hebben) kunnen inzien. Mijns inziens moeten deze bepaling en het oordeel van de Hoge Raad daarom worden uitgelegd in het licht van de

34 Rb. Midden-Nederland 5 november 2014, ECLI:NL:RBMNE:2014:5519 (Curatoren/SNS), r.o. 2.22.3 en Hof Amsterdam (OK) 9 december 2015, ECLI:NL:GHAMS:2015:5141, JOR 2016/7, m.nt. Bartman (Curatoren/SNS), r.o. 3.25 en 3.38-3.39.

35 Zie Rb. Rotterdam 29 september 2015, ECLI:NL:RBROT:2015:7610, JOR 2015/295, m.nt. Bartman (Iemants/Hertel Beheer), r.o. 4.12, waar de rechtbank oordeelt dat het feit dat de ultimate beneficial owners van de 403-maatschappij kapitaalkrachtig zijn en eerder een kapitaalstorting ten behoeve van de moedermaatschappij hebben gedaan, op zichzelf onvoldoende waarborg biedt. Zie ook Rb. Midden-Nederland 7 mei 2014, ECLI:NL:RBMNE:2014:1642, JOR 2014/260, m.nt. Harmsen (Curatoren/SNS), r.o. 3.18 en Hof Amsterdam (OK) 9 december 2015, ECLI:NL:GHAMS:2015:5141, JOR 2016/7, m.nt. Bartman (Curatoren/SNS), r.o. 3.25, dat de verwachting dat de Nederlandse Staat wegens macro-economische redenen 403-maatschappij SNS Bank niet failliet zal laten gaan, onvoldoende waarborg biedt.

36 HR 31 maart 2017, ECLI:NL:HR:2017:546, JOR 2017/221, m.nt. De Haan (SNS/Curatoren), r.o. 5.1.4. Zie ook Kamerstukken II 1983/84, 16551, nr. 11, p. 16 (NnavhEV).

37 Zie Bartman \& Van der Kraan 2017, p. 926 en Van der Kraan 2018, p. 9.

38 Hanegraaf 2019, p. 187. 
functie die de 403-aansprakelijkheid van de moedermaatschappij vervult bij deze compensatie.

Ik wees er in de inleiding al op dat een crediteur wordt gecompenseerd voor het niet (hebben) kunnen inzien van de jaarrekening van de 403-maatschappij, doordat hij op grond van de 403-verklaring een aanvullende vordering heeft op de moedermaatschappij, waarvan hij de geconsolideerde jaarrekening wel kan inzien. Deze compensatie betekent niet dat de crediteur zekerheid heeft dat zijn vordering op de moedermaatschappij volledig zal worden voldaan - net zoals iedere andere partij kan de moedermaatschappij immers failleren of anderszins tekortschieten in de nakoming. De crediteur wordt gecompenseerd voor het feit dat hij een vordering heeft op een debiteur - de 403-maatschappij - van wie hij de jaarrekening niet kan inzien, met een aanvullende vordering op een andere debiteur - de moedermaatschappij - van wie hij de jaarrekening wel kan inzien. Het is uiteindelijk aan de crediteur zelf om (mede) aan de hand van de jaarrekening van de moedermaatschappij te schatten hoe groot het risico is dat zijn vordering niet (volledig) zal worden voldaan en te beoordelen of hij dit risico accepteert of niet. Dit is niet anders dan wanneer de 403-maatschappij geen gebruik zou hebben gemaakt van de jaarrekeningvrijstelling. Ook dan moet de crediteur zelf (mede) aan de hand van de jaarrekening van de 403-maatschappij schatten hoe groot het risico is dat zijn vordering niet (volledig) zal worden voldaan en beoordelen of hij bereid is dit risico te accepteren of niet.

Vorenstaande brengt mee dat een crediteur zijn beslissing om een relatie met de 403-maatschappij aan te gaan of een bestaande relatie te continueren, niet (mede) heeft kunnen baseren op de informatie uit de jaarrekening van de 403-maatschappij. In plaats daarvan heeft hij deze beslissing (mede) kunnen baseren op de informatie uit de geconsolideerde jaarrekening van de moedermaatschappij. Het risico dat de crediteur (onbewust) heeft geaccepteerd toen hij de relatie met de 403-maatschappij is aangegaan of heeft gecontinueerd, is het risico dat de moedermaatschappij de vordering op grond van de 403-verklaring niet (volledig) voldoet. De vraag of de positie van de crediteur door de beëindiging van de overblijvende aansprakelijkheid verzwakt, moet naar mijn mening tegen vorenstaande achtergrond worden beantwoord. Dit betekent dat de waarborgen die de crediteur heeft dat zijn vordering op de moedermaatschappij zal worden voldaan, moeten worden vergeleken met de waarborgen die hij - na de beëindiging van de overblijvende aansprakelijkheid - heeft dat zijn vordering op de 403-maatschappij zal worden voldaan. Anders gezegd: een crediteur heeft recht op een vervangende waarborg als hij na de beëindiging van de overblijvende aansprakelijkheid niet minimaal dezelfde waarborgen heeft - uit hoofde van de vermogenstoestand van de 403-maatschappij of uit anderen hoofde - dat zijn vordering op de 403-maatschappij zal worden vol- 
daan, als de waarborgen die hij heeft dat zijn vordering op de moedermaatschappij zal worden voldaan. ${ }^{39} \mathrm{Ik}$ licht dit toe.

Stel dat het vooruitzicht is dat de moedermaatschappij de vordering van de crediteur op grond van de 403-verklaring voor de helft zal kunnen voldoen en dat daarnaast te verwachten is dat de vordering op de 403-maatschappij volledig zal worden voldaan. In dat geval heeft de crediteur geen recht op een vervangende waarborg. Maar ook als het niet waarschijnlijk is dat de 403-maatschappij de vordering van de crediteur volledig zal kunnen voldoen, is het mogelijk dat de crediteur geen recht heeft op een vervangende waarborg. Dit doet zich bijvoorbeeld voor als de verwachting is dat de vordering op de 403-maatschappij voor twee derde zal worden voldaan, maar dat de moedermaatschappij de vordering op grond van de 403-verklaring maar voor een kwart zal kunnen voldoen.

Overigens maak ik wel een nuancering met betrekking tot vorenstaande norm dat een crediteur recht heeft op een vervangende waarborg als hij na de beëindiging van de overblijvende aansprakelijkheid niet minimaal dezelfde waarborgen heeft dat zijn vordering op de 403-maatschappij zal worden voldaan, als de waarborgen die hij heeft dat zijn vordering op de moedermaatschappij zal worden voldaan. In het geval dat er redelijkerwijs geen twijfel bestaat dat de vordering van de crediteur op de 403-maatschappij volledig zal worden voldaan, maar dit desondanks minder waarborgen biedt dan de waarborgen die hij heeft dat zijn vordering op de moedermaatschappij zal worden voldaan - omdat de moedermaatschappij er financieel beter voor staat -, heeft de crediteur naar mijn mening geen recht op een vervangende waarborg.

Vorenstaande nuancering is ook terug te vinden bij twee uitspraken met betrekking tot het recht van verzet van een crediteur op grond van art. 2:316 en 2:334k BW bij een voorgenomen fusie, respectievelijk splitsing van zijn debiteur. ${ }^{40} \mathrm{Op}$ grond van deze bepalingen heeft een crediteur die verzet heeft ingesteld recht op een waarborg voor de nakoming van zijn vordering, tenzij hij al voldoende waarborgen heeft of de vermogenstoestand van de rechtspersoon die na de fusie respectievelijk de splitsing zijn debiteur zal zijn niet minder waarborgen zal bieden dat de vordering zal worden voldaan dan de vermogenstoestand van zijn huidige debiteur. Bij beide uitspraken bood de rechtspersoon die de debiteur was voor de fusie, respectievelijk de splitsing meer waarborgen dat de vordering van de crediteur zou worden voldaan dan de rechtspersoon die daarna de debiteur zou zijn. Het verzet van de crediteur is in beide gevallen echter afgewezen omdat het desondanks de verwachting was dat de crediteur na de fusie, respectievelijk de splitsing zijn vordering volledig voldaan zou krijgen. In 2003 oordeelt de rechtbank Amsterdam dat het vermogen waarop de crediteur zich voor en na de splitsing kan verhalen niet gelijk hoeft te zijn, maar dat dit wel een even grote waarborg moet bieden dat de

39 Vgl. H. ten Voorde, Deponering, publicatie en verzet. Een onderzoek naar de procedures rond vereffening, omzetting, kapitaalvermindering, fusie, splitsing en beëindiging van de overblijvende aansprakelijkheid uit een 403-verklaring (diss. Nijmegen), Deventer: Kluwer 2006, p. 148-149 en Van Zoest 2017, p. 65-66.

40 Rb. Amsterdam 4 april 2003, ECLI:NL:RBAMS:2003:AF6909, JOR 2003/105, m.nt. Wintgens-van Luyn (Dexia Bank Nederland) en Rb. Den Haag 21 februari 2019, ECLI:NL:RBDHA:2019:2195, JOR 2019/131, m.nt. Koster (Optas/Aegon). 
vordering zal worden voldaan. Hieraan is ook voldaan als zowel voor als na de splitsing voor de crediteur uitzicht bestaat op volledige voldoening van zijn vordering. ${ }^{41}$ Daarnaast heeft de rechtbank Den Haag in 2019 met betrekking tot een door een crediteur ingesteld verzet tegen een voorgenomen fusie geoordeeld dat het feit dat de crediteur na de fusie minder waarborgen zal hebben dat zijn vordering zal worden voldaan, niet zonder meer meebrengt dat het verzet gegrond wordt verklaard als het de verwachting is dat hij ook na de fusie zijn vordering volledig voldaan zal krijgen. ${ }^{42}$

\section{$5 \quad$ Welke omvang moet een vervangende waarborg hebben?}

Als vast is komen te staan dat een crediteur recht heeft op een vervangende waarborg, bepaalt de rechter wat voor een waarborg moet worden gegeven en binnen welke termijn. ${ }^{43}$ Ik merk op dat niet alleen de moedermaatschappij, maar ook een derde de vervangende waarborg kan geven aan de crediteur. Als een derde bijvoorbeeld de aandelen in de 403-maatschappij overneemt, kan zij met de moedermaatschappij hebben afgesproken dat zij eventuele vervangende waarborgen geeft aan de crediteuren, zodat de moedermaatschappij na de overdracht geen verdere aansprakelijkheid heeft. ${ }^{44}$

De crediteur moet zonder moeite verhaal kunnen halen op de vervangende waarborg. ${ }^{45}$ Deze waarborg kan iedere vorm van persoonlijke of zakelijke zekerheid zijn. ${ }^{46}$ Hierbij kan onder meer worden gedacht aan een borgstelling of een pand- of hypotheekrecht. Maar het is ook mogelijk dat er een geldbedrag ter beschikking wordt gesteld op de derdenrekening van een notaris of dat er een bankgarantie wordt afgegeven.

Indien de vervangende waarborg niet binnen de gestelde termijn wordt gegeven, wordt het verzet gegrond verklaard en is de overblijvende aansprakelijkheid van de moedermaatschappij tegenover de crediteur niet beëindigd. ${ }^{47}$ Binnen welke termijn de vervangende waarborg moet worden gegeven, hangt af van de omstandigheden van het geval. Hierbij kan worden gedacht aan de omvang en de soort waarborg die moet worden gegeven. Als de moedermaatschappij bijvoorbeeld een hypotheekrecht op een pand als vervangende waarborg wil geven, moet er genoeg tijd zijn om de executiewaarde van het pand vast te stellen, zodat kan worden beoordeeld of het hypotheekrecht voldoende waarborg biedt. In 2006 heeft de recht-

41 Rb. Amsterdam 4 april 2003, ECLI:NL:RBAMS:2003:AF6909, JOR 2003/105, m.nt. Wintgens-van Luyn (Dexia Bank Nederland), r.o. 4.11.

42 Rb. Den Haag 21 februari 2019, ECLI:NL:RBDHA:2019:2195, JOR 2019/131, m.nt. Koster (Optas/ Aegon), r.o. 4.10-4.13.

43 Zie art. 2:404 lid 5 en 6 BW.

44 Kamerstukken II 1983/84, 16551, nr. 11, p. 16 (NnavhEV).

45 Rb. Rotterdam 30 september 2014, ECLI:NL:RBROT:2014:8032, JOR 2014/326, m.nt. Loesberg (Pergen/Eneco), r.o. 4.19 en Rb. Rotterdam 29 september 2015, ECLI:NL:RBROT:2015:7610, JOR 2015/295, m.nt. Bartman (Iemants/Hertel Beheer), r.o. 4.15. Anders: Notenboom 2017, p. 131-132.

46 Ten Voorde 2006, p. 143. Zie ook Nass 2019, p. 155.

47 Nass 2019, p. 156. Zie bijv. Rb. Midden-Nederland 14 januari 2015, ECLI:NL:RBMNE:2015:51 (Curatoren/SNS), r.o. 2.2. 
bank 's-Hertogenbosch de termijn voor het geven van een vervangende waarborg van bijna $€ 27$ miljoen vastgesteld op één maand en twee dagen, ${ }^{48}$ de rechtbank Rotterdam heeft in 2014 een moedermaatschappij twee maanden de tijd gegeven om een vervangende waarborg van $€ 805$ miljoen te geven ${ }^{49}$ en een jaar later heeft zij de termijn voor het geven van een vervangende waarborg van $€ 15$ miljoen vastgesteld op één maand..$^{50}$

Volgens Beckman moet een vervangende waarborg overeenkomen met het bedrag van de nog openstaande vorderingen, evenals de in de toekomst nog te verwachten vorderingen van de crediteur op de 403-maatschappij - waarvoor de moedermaatschappij op grond van de ingetrokken 403 -verklaring aansprakelijk is. ${ }^{51}$ Dit standpunt wordt ondersteund door de jurisprudentie. Tot op heden hebben rechters telkens de te geven vervangende waarborg vastgesteld op het bedrag van de bestaande en toekomstige vorderingen van de crediteur op de 403-maatschappij. ${ }^{52}$ Naar mijn mening is het echter te kort door de bocht om de omvang van een te geven vervangende waarborg zonder meer vast te stellen op het bedrag van de bestaande en toekomstige vorderingen van de crediteur op de 403-maatschappij. Dit maakt het onnodig belastend voor een moedermaatschappij om de overblijvende aansprakelijkheid te beëindigen. Mijns inziens moet de omvang van de te geven vervangende waarborg mede worden vastgesteld aan de hand van de waarborgen die de crediteur al heeft, uit hoofde van de vermogenstoestand van de 403-maatschappij of uit anderen hoofde, dat zijn bestaande en toekomstige vorderingen op de 403-maatschappij zullen worden voldaan. De vervangende waarborg moet een aanvulling zijn op de waarborgen die de crediteur al heeft.

Aangezien een crediteur geen invloed heeft op de keuze van de moedermaatschappij om de overblijvende aansprakelijkheid te beëindigen, meen ik dat hij door deze beëindiging niet in een nadeliger positie mag komen ten opzichte van de situatie dat de overblijvende aansprakelijkheid niet zou zijn beëindigd. De vervangende waarborg moet daarom het nadeel dat de crediteur door de beëindiging ondervindt compenseren. Aan de andere kant moet naar mijn mening ook zo veel mogelijk worden voorkomen dat een crediteur door de beëindiging in een voordeliger positie komt. Waar mogelijk moet 'overcompensatie' worden vermeden.

48 Rb. 's-Hertogenbosch 3 maart 2006, ECLI:NL:RBSHE:2006:AX8557, JOR 2006/201 (De Plaet/NRE), r.o. 4.3.

49 Rb. Rotterdam 30 september 2014, ECLI:NL:RBROT:2014:8032, JOR 2014/326, m.nt. Loesberg (Pergen/Eneco), r.o. 4.19.

50 Rb. Rotterdam 29 september 2015, ECLI:NL:RBROT:2015:7610, JOR 2015/295, m.nt. Bartman (Iemants/Hertel Beheer), r.o. 4.14.

51 Beckman, in: Sdu Commentaar Ondernemingsrecht 2019, art. 2:404 BW, aant. C.2

52 Rb. 's-Hertogenbosch 3 maart 2006, ECLI:NL:RBSHE:2006:AX8557, JOR 2006/201 (De Plaet/NRE), r.o. 4.2, Rb. Rotterdam 30 september 2014, ECLI:NL:RBROT:2014:8032, JOR 2014/326, m.nt. Loesberg (Pergen/Eneco), r.o. 4.19, Rb. Midden-Nederland 5 november 2014, ECLI:NL:RBMNE: 2014:5519 (Curatoren/SNS), r.o. 2.3, Rb. Rotterdam 29 september 2015, ECLI:NL:RBROT:2015: 7610, JOR 2015/295, m.nt. Bartman (Iemants/Hertel Beheer), r.o. 4.13-4.14 en Hof Amsterdam (OK) 9 december 2015, ECLI:NL:GHAMS:2015:5141, JOR 2016/7, m.nt. Bartman (Curatoren/ SNS), r.o. 3.11. Bij de Iemants/Hertel Beheer-uitspraak is de vervangende waarborg overigens lager vastgesteld dan het bedrag van de vordering van de crediteur, omdat de 403-maatschappij eerder een deel van het bedrag van de vordering in escrow had geplaatst. 
Evenals bij de beoordeling of een crediteur recht heeft op een vervangende waarborg, ${ }^{53}$ meen ik dat de vraag welk nadeel de crediteur door de beëindiging van de overblijvende aansprakelijkheid ondervindt - en wat er dus met de te geven vervangende waarborg moet worden gecompenseerd -, moet worden beantwoord in het licht van de functie van de 403-aansprakelijkheid bij de compensatie van de crediteur. Ik heb eerder opgemerkt dat het risico dat een crediteur (onbewust) heeft geaccepteerd toen hij de relatie met de 403-maatschappij is aangegaan of heeft gecontinueerd, het risico is dat de moedermaatschappij de vordering op grond van de 403-verklaring niet (volledig) voldoet. Na de beëindiging van de overblijvende aansprakelijkheid kan de crediteur zich niet meer op de moedermaatschappij verhalen, maar alleen nog op de 403-maatschappij. Het nadeel dat de crediteur door de beëindiging van de overblijvende aansprakelijkheid ondervindt, betreft mijns inziens daarom het verschil in de waarborgen die de crediteur heeft dat zijn vordering op de moedermaatschappij zal worden voldaan, en de waarborgen die hij heeft dat zijn vordering op de 403-maatschappij zal worden voldaan. Dit brengt naar mijn mening mee dat de vervangende waarborg een aanvulling moet zijn op de waarborgen die de crediteur heeft - uit hoofde van de vermogenstoestand van de 403-maatschappij of uit anderen hoofde - dat zijn vordering op de 403-maatschappij zal worden voldaan. Gezamenlijk moet dit de crediteur (minimaal) dezelfde waarborgen bieden dat zijn vordering op de 403-maatschappij zal worden voldaan als de waarborgen die hij heeft dat zijn vordering op de moedermaatschappij zal worden voldaan. ${ }^{54} \mathrm{Ik}$ licht dit toe aan de hand van een voorbeeld. Stel dat de verwachting is dat de moedermaatschappij de vordering van de crediteur op grond van de 403-verklaring volledig zal voldoen. Daarnaast is te verwachten dat de 403-maatschappij de vordering van de crediteur voor twee derde zal voldoen. Ten aanzien van beide vorderingen gelden dezelfde voorwaarden omtrent de nakoming. ${ }^{55}$ De crediteur heeft geen waarborgen uit anderen hoofde dat zijn vordering op de 403-maatschappij zal worden voldaan. Aangezien de crediteur na de beëindiging van de overblijvende aansprakelijkheid minder waarborgen zal hebben dat zijn vordering op de 403-maatschappij zal worden voldaan, dan de waarborgen die hij heeft dat zijn vordering op de moedermaatschappij zal worden voldaan, heeft hij recht op een vervangende waarborg. Indien de huidige lijn in de jurisprudentie wordt gevolgd, moet de crediteur een vervangende waarborg worden gegeven die overeenkomt met het volledige bedrag van de vordering op de 403-maatschappij. Na de beëindiging van de overblijvende aansprakelijkheid heeft de crediteur dan een vordering op de 403-maatschappij - waarvan de verwachting

53 Zie par. 4 van deze bijdrage.

54 Vgl. Notenboom 2017, p. 133.

55 Krachtens art. 2:403 lid 1 sub f BW moet een moedermaatschappij zich op grond van een 403-verklaring hoofdelijk aansprakelijk stellen voor de schulden die voortvloeien uit de rechtshandelingen van de 403-maatschappij. Deze hoofdelijke aansprakelijkheid kan van invloed zijn op de waarborgen die de crediteur heeft dat zijn vorderingen op de moeder- en de 403-maatschappij zullen worden voldaan, en daarmee ook op het antwoord op de vraag of een crediteur recht heeft op een vervangende waarborg en welke omvang deze moet hebben. In verband met de reikwijdte van deze bijdrage laat ik deze discussie hier rusten en verwijs ik naar mijn proefschrift: Van Dooren 2021, p. 347349. 
is dat de 403-maatschappij deze voor twee derde zal voldoen - en een vervangende waarborg die gelijk is aan het volledige bedrag van deze vordering.

Indien daarentegen mijn redenering voor het bepalen van de omvang van een te geven vervangende waarborg wordt gevolgd, gaat het erom dat de crediteur na de beëindiging van de overblijvende aansprakelijkheid (minimaal) dezelfde waarborgen heeft dat zijn vordering op de 403-maatschappij zal worden voldaan als de waarborgen die hij heeft dat zijn vordering op de moedermaatschappij zal worden voldaan. Voor vorenstaand voorbeeld betekent dit dat de crediteur een vervangende waarborg moet worden gegeven die (minimaal) overeenkomt met een derde van het bedrag van de vordering op de 403-maatschappij. De crediteur heeft dan na de beëindiging van de overblijvende aansprakelijkheid evenveel waarborgen, uit hoofde van de vermogenstoestand van de 403-maatschappij en de vervangende waarborg gezamenlijk, dat zijn vordering op de 403-maatschappij zal worden voldaan als de waarborgen die hij had dat zijn vordering op de moedermaatschappij zou worden voldaan. Het resultaat van het op deze manier vaststellen van de omvang van de te geven vervangende waarborg is dat de crediteur geen nadeel ondervindt ten opzichte van de situatie dat de overblijvende aansprakelijkheid niet zou zijn beëindigd, maar dat het voor de moedermaatschappij minder belastend is om de overblijvende aansprakelijkheid te beëindigen omdat de crediteur een minder omvangrijke vervangende waarborg hoeft te worden gegeven.

Om de omvang van een vervangende waarborg op de door mij bepleite manier vast te stellen is geen wetswijziging nodig. Art. 2:404 lid 6 BW geeft een rechter de vrijheid om zelf de te geven vervangende waarborg te bepalen.

Ik ben mij er overigens van bewust dat het niet altijd eenvoudig zal zijn om de omvang van een te geven vervangende waarborg vast te stellen op de door mij voorgestelde wijze. Per crediteur aan wie een vervangende waarborg moet worden gegeven, moet namelijk worden vastgesteld welke waarborgen hij heeft dat zijn vorderingen op de moeder- en de 403-maatschappij zullen worden voldaan. De bewijslast hiervoor ligt bij de moedermaatschappij. Dit betekent echter niet dat de te geven vervangende waarborg daarom maar - volgens de huidige lijn in de jurisprudentie - moet worden vastgesteld op het bedrag van de bestaande en toekomstige vorderingen van de crediteur op de 403-maatschappij. Mij staat op dit punt een middenweg voor ogen.

Bij het bepalen van de te geven vervangende waarborg kan de rechter een schatting maken van de waarborgen die de crediteur heeft dat zijn vorderingen op de moeder- en de 403-maatschappij zullen worden voldaan. De rechter stelt de te geven vervangende waarborg dan niet vast op het bedrag van de bestaande en toekomstige vorderingen van de crediteur op de 403-maatschappij, maar hij maakt een schatting in hoeverre dit bedrag verminderd kan worden. Als de rechter een voorzichtige schatting maakt, waarbij hij in het bijzonder rekening houdt met het belang van de crediteur, is mijns inziens (voldoende) gewaarborgd dat de crediteur door de beëindiging van de overblijvende aansprakelijkheid niet in een nadeliger positie komt. 


\section{Verbreking van de groepsband}

Het laatste vereiste voor de beëindiging van de overblijvende aansprakelijkheid waar ik op wijs, is dat van art. 2:404 lid 3 sub a BW: de 403-maatschappij behoort niet meer tot de groep van de moedermaatschappij. In de literatuur is veel kritiek geuit op deze voorwaarde, omdat dit een onnodige drempel zou opwerpen om de overblijvende aansprakelijkheid te beëindigen. ${ }^{56}$

Houwen merkt op dat het vereiste van het verbreken van de groepsband een overblijfsel is van de voorloper van de huidige regeling inzake de beëindiging van de overblijvende aansprakelijkheid: het oude art. 2:403 lid 2 BW. ${ }^{57}$ Op grond van die bepaling eindigde de overblijvende aansprakelijkheid van de moedermaatschappij drie jaar nadat de groepsband met de 403-maatschappij was verbroken. Volgens Houwen was het idee van deze regeling dat de moedermaatschappij niet voor altijd aansprakelijk zou moeten blijven als zij geen doorslaggevende zeggenschap meer had ten aanzien van de 403-maatschappij. Vanuit die optiek is het verbreken van de groepsband volgens hem geen onbegrijpelijke voorwaarde voor de beëindiging van de overblijvende aansprakelijkheid. Houwen merkt op dat met de invoering van de huidige regeling van art. 2:404 lid 3 tot en met 6 BW waarborgen zijn geïntroduceerd met betrekking tot het verhaalsrecht van een crediteur tegenover de moedermaatschappij. Een crediteur kan verzet instellen tegen het voornemen van de moedermaatschappij om de overblijvende aansprakelijkheid te beëindigen en een vervangende waarborg verlangen. In de huidige regeling zijn de belangen van de crediteuren volgens hem zodanig gewaarborgd dat de moedermaatschappij de overblijvende aansprakelijkheid moet kunnen beëindigen, ongeacht of de groepsband met de 403-maatschappij is verbroken.

Ik sluit mij aan bij vorenstaand standpunt dat de voorwaarde dat de groepsband tussen de moeder- en de 403-maatschappij is verbroken, onnodig belastend is om de overblijvende aansprakelijkheid te beëindigen. Ik heb hiervoor opgemerkt dat ik van mening ben dat aangezien een crediteur geen invloed heeft op de keuze van de moedermaatschappij om de overblijvende aansprakelijkheid te beëindigen, hij door deze beëindiging niet in een nadeliger positie mag komen ten opzichte van de situatie dat de overblijvende aansprakelijkheid niet zou zijn beëindigd. Dit betekent in de eerste plaats dat de crediteur weer de mogelijkheid moet hebben om de

56 Houwen, Schoonbrood-Wessels \& Schreurs 1993, p. 856-857, Beckman 1995a, p. 99, M.J. Blommaert, Beëindiging van de 403-aansprakelijkheid, Journaal IF\&Z 2007, afl. 7/8, p. 276 en Van Zoest 2016, p. 62. Zie ook Beckman 1995b, p. 613, die opmerkt dat het voor derden niet altijd duidelijk is of de groepsband tussen de moeder- en de 403-maatschappij is verbroken.

57 Houwen, Schoonbrood-Wessels \& Schreurs 1993, p. 856-857. 
jaarrekening van de 403-maatschappij in te zien. ${ }^{58}$ Daarnaast moet hij een vervangende waarborg kunnen krijgen, waardoor hij na de beëindiging (minimaal) dezelfde waarborgen heeft dat zijn vordering op de 403-maatschappij zal worden voldaan als de waarborgen die hij had dat zijn vordering op de moedermaatschappij zou worden voldaan. Als aan deze voorwaarden is voldaan, zou er naar mijn mening verder niets in de weg moeten staan aan de beëindiging van de overblijvende aansprakelijkheid.

Daarnaast wijs ik erop dat het vereiste dat de groepsband met de 403-maatschappij moet worden verbroken om de overblijvende aansprakelijkheid te kunnen beëindigen een moedermaatschappij zelfs kan afschrikken om zich op grond van een 403-verklaring aansprakelijk te stellen. De moedermaatschappij weet van tevoren dat als zij een 403-verklaring deponeert en zij in de toekomst de overblijvende aansprakelijkheid wil beëindigen, dit mogelijk tot verlies van synergie binnen de groep leidt doordat zij de 403-maatschappij moet afstoten. De moedermaatschappij kan besluiten dat de aansprakelijkheid op grond van de 403-verklaring en de voorwaarden om deze aansprakelijkheid later te beëindigen - waaronder het verbreken van de groepsband met de 403-maatschappij - niet opwegen tegen het voordeel dat zij verwacht te behalen door zich op grond van deze verklaring aansprakelijk te stellen. De 403-maatschappij kan dan niet gebruikmaken van de jaarrekeningvrijstelling van het groepsregime.

Resumerend ben ik van mening dat het vereiste van het verbreken van de groepsband tussen de moeder- en de 403-maatschappij de beëindiging van de overblijvende aansprakelijkheid onnodig moeilijk maakt en dat de jaarrekeningvrijstelling van het groepsregime daardoor minder toegankelijk is. Ik pleit er daarom voor dat deze voorwaarde wordt geschrapt uit art. 2:404 lid 3 BW.

\section{Conclusie: naar een nieuwe regeling voor de beëindiging van de overblij- vende aansprakelijkheid}

In deze bijdrage heb ik een voorstel gedaan voor een nieuwe regeling voor de beëindiging van de overblijvende aansprakelijkheid. Ik betoog dat het huidige art. 2:404 lid 3 tot en met 6 BW op bepaalde punten anders moet worden uitgelegd in de jurisprudentie, en dat de regeling daarnaast op sommige plekken moet worden gewijzigd.

58 Ik merk op dat het naar huidig recht mogelijk is dat de moedermaatschappij de 403-verklaring intrekt en de overblijvende aansprakelijkheid beëindigt voordat de 403-maatschappij weer een jaarrekening openbaar heeft gemaakt. Er is dan een periode dat crediteuren de jaarrekening van de 403-maatschappij niet kunnen inzien, maar daarvoor niet worden gecompenseerd. Ik acht deze lacune in de compensatie van de crediteuren onwenselijk en bepleit daarom dat art. 2:404 lid 1 BW wordt aangepast, zodat de intrekking van een 403-verklaring slechts of eerst effect heeft als de 403-maatschappij een jaarrekening openbaar heeft gemaakt die aan de voorschriften van titel 9 van Boek 2 BW voldoet, of als er een nieuwe 403-verklaring is gedeponeerd ten aanzien van de 403-maatschappij. In verband met de reikwijdte van deze bijdrage laat ik deze discussie hier rusten en verwijs ik naar mijn proefschrift: Van Dooren 2021, p. 257-262 en 300-302. 
Op basis van de door mij voorgestelde wijzigingen met betrekking tot de (uitleg van de) regeling van de beëindiging van de overblijvende aansprakelijkheid zou kunnen worden gedacht dat mij een regeling voor ogen staat die vooral in het voordeel is van de crediteuren. Ik ben bijvoorbeeld van mening dat de Kamer van Koophandel een systeem zou moeten aanbieden waarbij crediteuren automatisch een notificatie kunnen krijgen als de moedermaatschappij een mededeling deponeert van het voornemen om de overblijvende aansprakelijkheid te beëindigen (zie par. 2). Hierdoor zullen waarschijnlijk meer crediteuren verzet instellen tegen dit voornemen. Daarnaast onderschrijf ik het oordeel van de Hoge Raad dat ook crediteuren met een niet-vaststaande vordering verzet kunnen instellen, tenzij de vordering onmiskenbaar ongegrond is (zie par. 3). ${ }^{59}$ Toch staat mij een regeling voor ogen die in haar geheel gezien het voor een moedermaatschappij eenvoudiger maakt om de overblijvende aansprakelijkheid te beëindigen. Ik ben inderdaad van mening dat crediteuren meer in de gelegenheid moeten worden gesteld om verzet in te stellen, maar ik meen ook dat het afwikkelen van verzet minder belastend moet zijn voor de moedermaatschappij.

Mijn belangrijkste punt van kritiek ziet op de huidige lijn in de jurisprudentie dat een te geven vervangende waarborg zonder meer wordt vastgesteld op het bedrag van de bestaande en toekomstige vorderingen van de crediteur op de 403-maatschappij. Deze uitleg van de omvang van een vervangende waarborg kan ertoe leiden dat de moedermaatschappij in één keer een groot bedrag als waarborg moet geven aan de crediteur. Dit werkt in de hand dat de moedermaatschappij probeert om zo min mogelijk ruchtbaarheid te geven aan de procedure voor de beëindiging van de overblijvende aansprakelijkheid om ervoor te zorgen dat de kans dat de crediteuren hiervan op de hoogte raken zo klein mogelijk is. Als een crediteur niet op de hoogte is van het voornemen van de moedermaatschappij om de overblijvende aansprakelijkheid te beëindigen, zal deze ook geen verzet instellen. De moedermaatschappij hoeft dan geen vervangende waarborg te geven en is bevrijd van haar aansprakelijkheid.

Mij staat een regeling voor ogen waarbij het voor de moedermaatschappij minder belastend is om de overblijvende aansprakelijkheid te beëindigen en waarbij ze wordt gestimuleerd om ervoor te zorgen dat de 403-maatschappij financieel gezond is. Ik wijs op drie punten. Ten eerste meen ik dat het oordeel van de Hoge Raad in de SNS/Curatoren-beschikking ${ }^{60}$ zo moet worden uitgelegd dat een crediteur recht heeft op een vervangende waarborg als hij na de beëindiging van de overblijvende aansprakelijkheid, uit hoofde van de vermogenstoestand van de 403-maatschappij of uit anderen hoofde, niet (minimaal) dezelfde waarborgen heeft dat zijn vordering op de 403-maatschappij zal worden voldaan als de waarborgen die hij heeft dat zijn vordering op de moedermaatschappij zal worden vol-

59 HR 31 maart 2017, ECLI:NL:HR:2017:546, JOR 2017/221, m.nt. De Haan (SNS/Curatoren), r.o. 5.1.6.

60 HR 31 maart 2017, ECLI:NL:HR:2017:546, JOR 2017/221, m.nt. De Haan (SNS/Curatoren), r.o. 5.1.4. 
daan, tenzij de crediteur redelijkerwijs geen risico loopt dat zijn vordering op de 403-maatschappij niet zal worden voldaan (zie par. 4).

Daarnaast meen ik dat de omvang van een te geven vervangende waarborg anders moet worden vastgesteld dan tot op heden in de jurisprudentie is gedaan. Een te geven vervangende waarborg dient mijns inziens een aanvulling te zijn op de waarborgen die de crediteur al heeft, uit hoofde van de vermogenstoestand van de 403-maatschappij of uit anderen hoofde, dat zijn vordering op de 403-maatschappij zal worden voldaan. Gezamenlijk moet dit de crediteur (minimaal) dezelfde waarborgen bieden dat zijn vordering op de 403-maatschappij zal worden voldaan als de waarborgen die hij heeft dat zijn vordering op de moedermaatschappij zal worden voldaan (zie par. 5).

De door mij bepleite uitleg van het recht van een crediteur op een vervangende waarborg en de omvang van deze waarborg stimuleren een moedermaatschappij om ervoor te zorgen dat de 403-maatschappij financieel gezond is als de overblijvende aansprakelijkheid wordt beëindigd. Hoe beter de vermogenstoestand van de 403-maatschappij, hoe minder waarschijnlijk het is dat een crediteur recht heeft op een vervangende waarborg, en - indien toch een waarborg moet worden gegeven - hoe kleiner de vervangende waarborg is die de moedermaatschappij moet geven. Ik verwijs naar mijn proefschrift voor een drietal rekenvoorbeelden, waarbij ik voor verschillende casus uitwerk of een crediteur recht heeft op een vervangende waarborg en welke omvang de te geven waarborg in dat geval (minimaal) moet hebben. ${ }^{61}$

Een derde aanpassing ten aanzien van de huidige regeling voor de beëindiging van de overblijvende aansprakelijkheid waar ik voor pleit, is dat het vereiste van het verbreken van de groepsband tussen de moeder- en de 403-maatschappij wordt geschrapt. Deze voorwaarde is een overblijfsel van de voorloper van de huidige regeling en is overbodig geworden door de introductie van de mogelijkheid voor crediteuren om verzet in te stellen tegen de beëindiging van de overblijvende aansprakelijkheid en een vervangende waarborg te verlangen. Door het schrappen van het vereiste van het verbreken van de groepsband wordt het eenvoudiger om de overblijvende aansprakelijkheid te beëindigen en gaat dit niet ten koste van synergie binnen de groep. 